\title{
FACTORS INVOLVED WITH CADMIUM ABSORPTION BY A WILD-TYPE STRAIN OF SACCHAROMYCES CEREVISIAE
}

\author{
Paula D.B. Adamis ${ }^{1}$; Anita D. Panek ${ }^{1}$; Selma G.F. Leite ${ }^{2}$; Elis C.A. Eleutherio ${ }^{1 *}$ \\ ${ }^{1}$ Departamento de Bioquímica, Instituto de Química, Universidade Federal do Rio de Janeiro, Rio de Janeiro, RJ, Brasil; \\ ${ }^{2}$ Escola de Química, Rio de Janeiro, RJ, Brasil
}

Submitted: October 16, 2001; Returned to authors for corrections: February 26, 2002; Approved: January 09, 2003

\begin{abstract}
At the concentration used in this work (10 ppm), cadmium was efficiently removed from the environment by stationary yeast cells. While exponential phase cells showed low capacity of cadmium absorption, stationary cells removed $97 \%$ of the original metal in 24 hours. Total cadmium absorption shown by dry cells was lower than that of fresh ones, although both cells removed $50 \%$ of metal during the first hour of treatment. We also verified that only viable cells were capable of absorbing cadmium. Independently of the growth phase, cells showed high tolerance to $10 \mathrm{ppm} \mathrm{CdSO}_{4}$ and about $80 \%$ of cells remained viable after 24 hours exposure to cadmium. However, when stationary phase cells were previously dehydrated and then exposed to cadmium, they exhibited poor survival. By using an oxidation-dependent fluorescent probe, we observed that, once absorbed by cells, cadmium increases the intracellular level of oxidation, which may be responsible for its toxic effect. Crude extracts from stationary phase cells exposed to cadmium showed a 10-fold increase in fluorescence, while extracts from cells of exponential phase did not increase in fluorescence. Dry cells treated with the metal showed a high increase in fluorescence, mainly caused by dehydration.
\end{abstract}

Key words: Saccharomyces cerevisiae, cadmium, absorption, intracellular oxidation

\section{INTRODUCTION}

Pollution of the environment by toxic metals arises as a result of many industrial activities and has turned these metal ions into a major health issue. When considering environmental impact of metallic species, mercury, lead and cadmium are in focus. While the use of mercury and lead is limited and does not mark an increasing trend, cadmium and its compounds were classified Carcinogens Category 2, i.e., probably human carcinogens (3).

With the increased use, cadmium represents a recognized great hazard potential to humans and to the environment $(9,13)$. Industrially, cadmium is produced solely as a by-product from extraction of zinc and lead. It is used in rechargeable batteries, specialized electronic equipment, bearing alloys, pigments (yellow and red) for ceramic glazes, paints and plastics. It is also present in phosphate fertilizers and fungicides (1). The concern arises because it accumulates in particular food species, with potential consequences to human health (21). Cadmium has been correlated with hypertension, reduced life span, prostate cancer, suppression of testicular function and disruption of a number of enzyme systems (13). It is a heavy metal that exhibits both acute and chronic toxicity. In cases of severe acute exposure, death can result in few days and long term exposure to lesser amounts can result in damage to kidney, lung and bone tissue (4). In 1997, cadmium was ranked number 7 by the Agency for Toxic Substances and Disease Registry / Environmental Protection Agency "Top 20 Harzadous Substances Priority List" (16).

Although $\mathrm{Cd}^{2+}$ has been implicated as a pro-oxidant (3), it differs from other pro-oxidant metal ions like $\mathrm{Cu}^{2+}$ and $\mathrm{Fe}^{2+}$ because it does not participate in redox cycling (22). Cadmium

* Corresponding author. Mailing address: Departamento de Bioquímica, Instituto de Química, Universidade Federal do Rio de Janeiro. 21949-900, Rio de Janeiro, RJ, Brasil. Telephone: (+5521) 2562-7824. Fax: (+5521) 2562-7266. E-mail: eliscael@iq.ufrj.br 
does not appear to generate free radicals, but does elevate lipid peroxidation in yeast cells soon after exposure (14).

It is important to study the effects of cadmium toxicity in higher eukaryotes, including humans. Saccharomyces cerevisiae, the preferred model for studies of stress in eukaryotic cells, is a useful organism for the identification of molecular mechanisms that control sensitivity to metal. The use of lower organisms, like yeast cells, as model systems is particularly attractive because of the facility in genetic manipulation, the availability of the complete Saccharomyces cerevisiae genomic sequence and the apparent conservation of molecular mechanisms between yeast and human cells.

Furthermore, microorganisms have all been reported to remove heavy metals from solutions, a fact which could have industrial applications for detoxifying effluents (9). On the other hand, biological effects of such metal pollutants on microorganisms can be considered as an indicator in bioassay systems. Yeast has received attention in connection with metal absorption, particularly because waste fungal biomass arises as a by-product from several industrial fermentations (17).

In the face of the importance of this subject, we analyzed cadmium absorption, survival and the level of intracellular oxidation using a wild type strain of Saccharomyces cerevisiae, in the presence of $10 \mathrm{ppm} \mathrm{CdSO}_{4}$.

\section{MATERIALS AND METHODS}

\section{Yeast strain}

The wild-type strain of Saccharomyces cerevisiae used in this study was purified from commercial baker's yeast.

\section{Culture conditions}

Cells were routinely maintained on solid YPAD medium containing $2.0 \%$ glucose, $2.0 \%$ peptone, $1.0 \%$ yeast extract, $0.01 \%$ adenine and $2.0 \%$ agar $(\mathrm{w} / \mathrm{v})$. For the experiments, cells were grown in liquid YED-glucose medium, pH 5.2 (2.0\% glucose, $1.3 \%$ yeast extract, $0.2 \% \mathrm{NH}_{4} \mathrm{SO}_{4}, 0.2 \% \mathrm{KH}_{2} \mathrm{PO}_{4}$ ) at $28^{\circ} \mathrm{C}$ and $160 \mathrm{rpm}$.

\section{Cadmium stress}

Cells were harvested by centrifugation and washed twice with $50 \mathrm{mM}$ phosphate buffer, $\mathrm{pH}$ 6.0. Thereafter, $200 \mathrm{mg}$ of cells (dry weight) were resuspended in $50 \mathrm{~mL}$ of the same

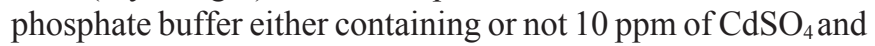
maintained at $28^{\circ} \mathrm{C} / 160 \mathrm{rpm}$. Aliquots were withdrawn at time intervals to analyze cell viability, cadmium determination as well as intracellular oxidation.

\section{Cell death}

Death of cells was performed by autoclaving at $111^{\circ} \mathrm{C}$ and $0.5 \mathrm{Kgf} / \mathrm{cm}^{2}$ for $15 \mathrm{~min}$. Cell death was confirmed by the methylene blue method (19). Cells that stained blue were considered nonviable.

\section{Heat treatment}

Cells were harvested in first exponential phase and then submitted to a heat treatment at $40^{\circ} \mathrm{C}$ for 60 minutes / $160 \mathrm{rpm}$, to try to induce resistance to stress (8). Cell viability was determined before and after heat treatment.

\section{Dehydration}

Cells were harvested in stationary phase, washed twice with

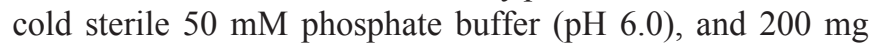
samples were left to dry to constant weight in an oven at $30^{\circ} \mathrm{C}$ (7). Rehydration of the dried samples was carried out with buffer either containing or not $10 \mathrm{ppm}$ of $\mathrm{CdSO}_{4}$, warmed at $40^{\circ} \mathrm{C}$ to avoid cell leakage (7). Cell viability was determined before and after dehydration /rehydration.

\section{Cell viability}

Before and following stress, cells were diluted with $50 \mathrm{mM}$ phosphate buffer ( $\mathrm{pH} \mathrm{6.0)}$ ) and plated on YPAD plates to estimate survival. Colonies were counted after incubation at $28^{\circ} \mathrm{C}$ for 72 hours. Plates were done in triplicates. Tolerance was measured as percentage of cells which survive stress. Viability of cells was analyzed before and after 1, 3, 5 and 24h of exposure

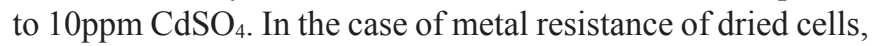
the rate of survival was calculated in relation to the number of viable cells after dehydration, and in the case of metal resistance of pre-heated cells, the rate of survival was calculated in relation to the number of viable cells after $40^{\circ} \mathrm{C}$.

\section{Cadmium determination}

We used the analytical technique of atomic absorption spectroscopy, which has the advantage of being able to quantify metal ions at trace levels with high selectivity $(10,18)$. For measuring cadmium concentration free in the medium, $5 \mathrm{~mL}$ aliquots were centrifuged; the supernatant solution was collected and subjected to atomic absorption spectrophotometry (Atomic Absorption Spectrometer, Perkin Elmer 3100). Cadmium absorption was estimated by determining the difference in metal content between control medium without biomass and test medium containing biomass. The concentration of cadmium free in the medium was determined after 1,3,5 and $24 \mathrm{~h}$.

\section{Fluorescence assays}

Direct molecular evidence of in vivo intracellular oxidation using the oxidant-sensitive probe 2', 7'-dichlorofluorescein was used to measure the levels of oxidation developed during exposure to cadmium. Fluorescence was measured using a PTI (Photo Technology International) spectrofluorimeter set at an excitation wavelength of $504 \mathrm{~nm}$ and an emission wavelength of $524 \mathrm{~nm}$ (6). Cells were harvested from cultures by centrifugation, washed twice with $50 \mathrm{mM}$ phosphate buffer $\mathrm{pH}$ 6.0 and $200 \mathrm{mg}$ of cells (dry weight) were resuspended in $50 \mathrm{~mL}$ of the same buffer. Dichlorofluorescein was added from a fresh 
$5 \mathrm{mM}$ stock in ethanol to a final concentration of $10 \mu \mathrm{M}$ and incubation continued for 15 minutes to allow uptake of the probe. Cadmium was added at the appropriate concentration and incubation continued. Cells $(50 \mathrm{mg})$ were harvested by centrifugation and washed twice with $50 \mathrm{mM}$ phosphate buffer $\mathrm{pH}$ 6.0. The pellet was resuspended in $500 \mu \mathrm{L}$ of the same buffer and $1.5 \mathrm{~g}$ of glass beads were added. The samples were lysed by three cycles of one minute agitation on a vortex mixer followed by one minute on ice. The supernatant solution was obtained after centrifugation at 13,000 rpm for 5 minutes, diluted 6 -fold with water and, then, fluorescence was measured. Fluorescence of crude extracts from cells of Saccharomyces cerevisiae treated with $10 \mu \mathrm{M} 2^{\prime}$ '-7' dichlorofluorescein, prepared at 1,3,5,7 and $24 \mathrm{~h}$ after addition of $10 \mathrm{ppm} \mathrm{CdSO}_{4}$ to the medium. As control, fluorescence was measured in cells not exposed to cadmium.

\section{RESULTS AND DISCUSSION}

Since the yeast physiological state is one of the most important factors, which influence metal absorption activity, cells from different growth phases were tested. Growth and proliferation of microorganisms such as the yeast Saccharomyces cerevisiae are controlled in part by availability of nutrients. When proliferation yeast cells exhaust available nutrients, they enter a stationary phase characterized by cell cycle arrest and specific physiological, biochemical, and morphological changes. These changes include thickening of the cell wall, accumulation of reserve carbohydrates, and acquisition of thermotolerance (27). According to Fig. 1, fresh cells harvested in stationary growth phase (at cell concentration of $4 \mathrm{mg}$ dry weight $/ \mathrm{mL}$ ), demonstrated a high capacity of cadmium absorption. Removal of cadmium by stationary phase cells occurred rapidly and high uptake levels were achieved within 3 hours. After the first hour, cells had sequestered more than $50 \%$ of the metal from the buffer, while after 3 hours almost 90\% were taken up. Exogenous cadmium concentration was greatly reduced after 24 hours of treatment with an efficiency of $97 \%$. Although each mg of cell (dry weight) contained around $0.0025 \mathrm{mg}$ of cadmium at the end of treatment, this value could be increased since cells demonstrated a high tolerance to the metal. By plating cells on solid medium containing cadmium, no growth inhibition was found up to 100 ppm CdSO4 (results not shown).

In some cases, dead cells can take up heavy metals in nature, when removal is due to purely physical / chemical interactions between the biomass and metal in solution (17). Microorganisms contain multiple binding sites for metals such as phosphate, carboxyl and sulphydryl groups, none of which are likely to be specific for one type of metal (26). However, we observed that dead cells of Saccharomyces cerevisiae were not capable of removing metal from solution (Fig. 1), indicating that the

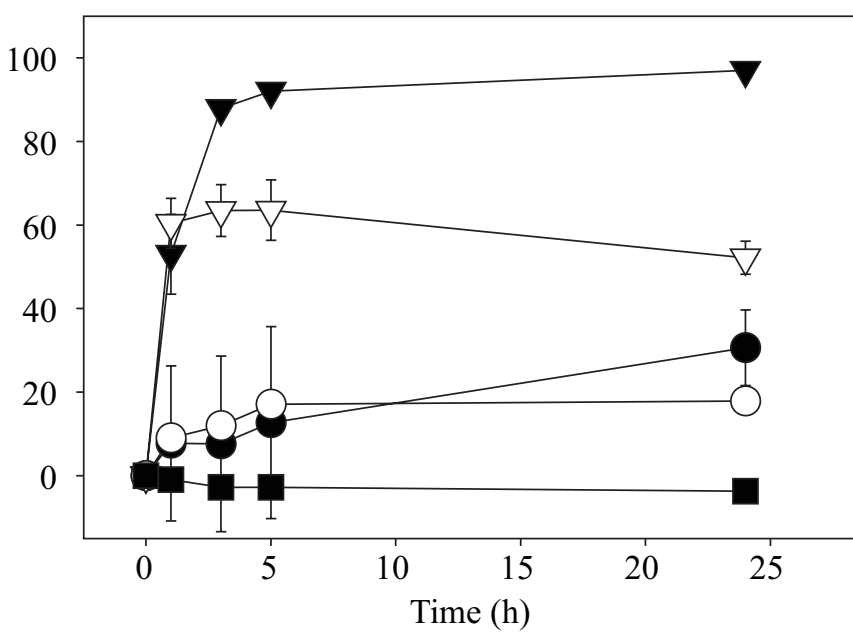

Figure 1. Cadmium absorption by dead cells $(\boldsymbol{\square})$, exponential non pre-heated cells $(-)$, exponential cells treated at $40^{\circ} \mathrm{C} / 1 \mathrm{~h}$ $(\mathrm{O})$, stationary fresh cells $(\boldsymbol{\nabla})$ and stationary dried cells $(\nabla)$. The results represent the mean and standard deviation of at least three independent experiments. Bars for some points may be smaller than plot symbols.

absorption of cadmium by yeast cells is dependent on metabolism. Cation transporters offer potential pathways for toxic metals (5). Non-essential heavy metal ions such as cadmium are most likely taken up via nutrient transporters or channels that are not selective. For example, IRT1, which is a membrane transporter involved in $\mathrm{Fe}^{2+}$ uptake, seems to be involved with accumulation of cadmium in plants (12). Recently, it was demonstrated that Saccharomyces cerevisiae deleted in ZRTI was not able to remove cadmium from the medium, suggesting that absorption of this metal by yeast cells is dependent on this zinc transporter (11).

We also employed dried cells in our experiments. Dehydration is a harmful stress, which induces physiological disturbances in biomolecules (7). However, anhydrobiotic organisms, like baker's yeasts, are able to survive in complete dehydration because they produce specific adaptive responses against alterations in solute concentration, which prevent loss of structural and functional integrity of dried membranes and proteins. According to Fig. 1, during the first hour of exposure to cadmium, dry cells absorbed the same quantity of metal than fresh cells. However, after 24 hours of treatment, $40 \%$ of the initial cadmium were still present in the medium.

Biomass harvested in first exponential phase (at cell concentration of $1 \mathrm{mg}$ dry weight $/ \mathrm{mL}$ ) was not capable of reducing the cadmium concentration of the medium to low levels. Almost $60 \%$ of the initial cadmium remained at the end of treatment. In addition, when exponential cells were treated at $40^{\circ} \mathrm{C} / 1 \mathrm{~h}$, their capacity of absorbing cadmium did not increase. 


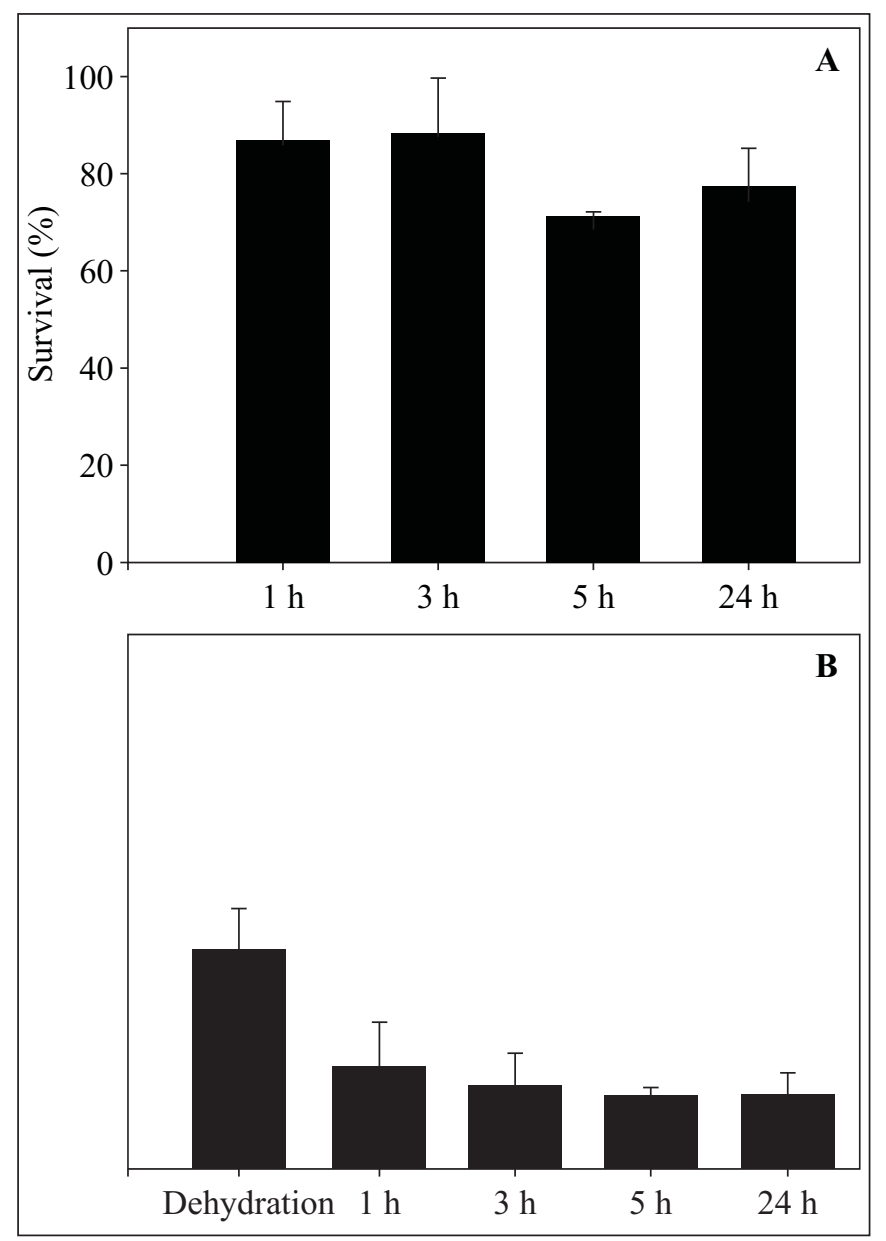

Figure 2. Effect of cadmium on survival of stationary phase cells. Experiments were done using fresh (A) or dry cells (B). Results represent the mean and standard deviation of at least three independent experiments.

The presence of $10 \mathrm{ppm} \mathrm{CdSO}_{4}$ did not impair the survival of stationary phase nor exponential growing cells (Figs. 2 and 3). Generally proliferating yeast cells are sensitive to severe stress. However, they can acquire tolerance after exposure to a moderate rise in temperature, which triggers specific genetic responses that protect cell against various kinds of damage (8). In our conditions, first exponential phase cells showed a high survival in the presence of the metal and the heat treatment did not improve the resistance to cadmium stress. Thus according to our results, $10 \mathrm{ppm}$ of cadmium does not pose much of a hazard to the cell. Indeed, exposure to low levels may increase resistance to subsequent higher levels by the induction of defense mechanisms. The lost of water produced a significant reduction in survival rates: however, almost $50 \%$ of cells still viable after dehydration (Fig. 2B). Cells in the dry state became

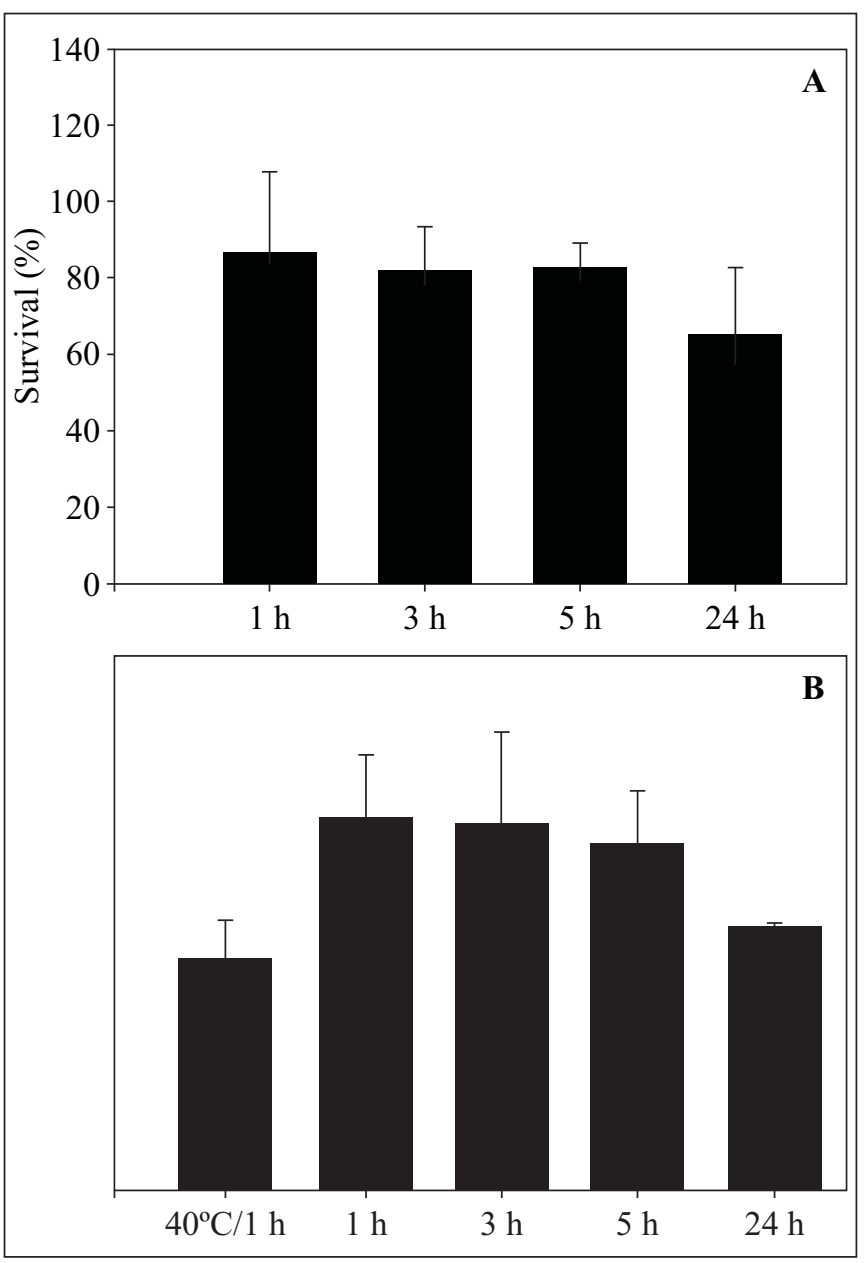

Figure 3. Effect of cadmium on survival of first exponential phase cells. Experiments were done using exponential cells (A) or exponential cells treated at $40^{\circ} \mathrm{C} / 1 \mathrm{~h}(\mathrm{~B})$. Results represent the mean and standard deviation of at least three independent experiments.

sensitive to metal stress, which was reflected in their lower cadmium absorption ability. Since dehydration caused a high increase in the intracellular oxidation (Fig. 4B), the toxic effect of cadmium, which is also associated with oxidation, might be intensified in dried cells. During the first hour of treatment, dried cells showed a higher capacity of absorbing cadmium than fresh cells, if we take into consideration the reduced amount of viable cells in the dried biomass. Most probably permeability of dried yeasts increases sharply during rehydration. According to the literature, a considerable leakage of free amino acids was observed after rehydration, whereas only traces of amino acids were released from intact cells (2). During rehydration, the change of permeability could also account for reverse processes - entering of substances into the cell (2). It has been also shown, 


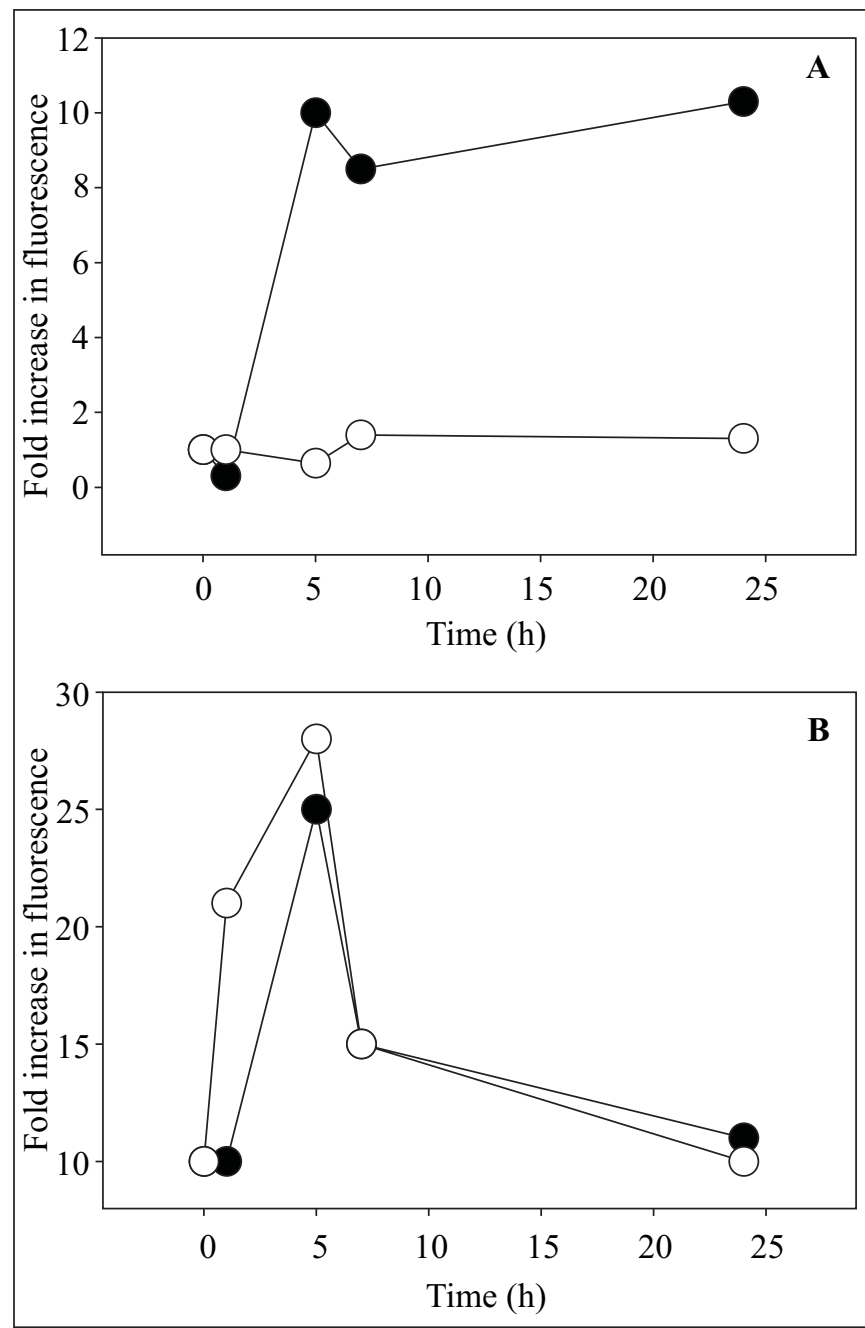

Figure 4. Level of intracellular oxidation. Panel A shows the intracellular oxidation of crude extracts from stationary cells $(-)$ and first exponential phase cells $(O)$. Panel B shows the intracellular oxidation after dehydration / rehydration $(\bullet)$ and after dehydration / rehydration in the presence of cadmium (O). The results represent the mean of at least three independent experiments.

that after a $1.5 \mathrm{~h}$ of rehydration the permeability of cytoplasmic membrane sharply decreases and brings it close to that of the intact organisms. This data brings support to our results, which showed constant cadmium absorption after the first hour.

According to literature, cadmium seems to induce an oxidative stress (3), which may be responsible for the toxic effects of this metal and could affect its uptake. Oxidative stress arises when cellular defenses and / or repair mechanisms against oxidative damage are compromised or overwhelmed by excessive generation of oxidative species (25). Intracellular accumulation of cadmium has been associated with different mechanisms of detoxification such as formation of complexes with metallothioneins (23). Cadmium reacts with intracellular thiols, such as cysteine residues and glutathione, mobilizing cellular defenses against free radicals generated by cellular metabolism and other environmental insults (15).

In this work, measuring changes in fluorescence resulting from an intracellular probe oxidation monitored intracellular oxidative stress produced by cadmium. The probe 2 ' -7 ' dichlorofluorescein is a molecule that can permeate cell membrane by passive diffusion (28). Once inside the cell, it becomes susceptible to attack by free radical species, producing a more fluorescent compound $(24,20)$. The intensity of fluorescence can be measured and it is the basis of commonly assay used for oxidative stress. Fig. 4 shows the relation between the fluorescence of cadmium stressed and non-stressed cells. According to Fig. 4A, while crude extracts from stationary phase cells showed a 10 -fold increase in fluorescence over a $5 \mathrm{~h}$ period, fluorescence of extracts obtained from exponential phase cells did not change significantly.

Results obtained suggested that the generation of reactive oxygen species is related to the quantity of cadmium absorbed by the cells. Stationary phase cells, which remove practically all the cadmium from the medium, showed an increased level of intracellular oxidation, while with first exponential phase cells, which absorbed only $40 \%$ of the initial metal, only a small induction of oxidative fluorescence was observed. Dehydration enhanced the level of cellular oxidation, as was expected, since biomolecules in the dry state are more susceptible to the attack by reactive oxygen species (2). The effect of cadmium on oxidation of dried cells was low, probably because intracellular oxidation had been greatly increased after removal of water.

In conclusion, the results obtained showed an increased intracellular oxidation during cadmium exposure, which seems to be related to metal uptake. A complete understanding of the molecular basis of sensitivity to toxic metals in lower organisms is expected to provide useful insights into the metal ion detoxification pathways, human related diseases and removal of heavy metals from the environment. Future studies will be aimed at elucidating the mechanisms of adaptation of cells to cadmium exposure, which may produce broad biotechnological applications.

\section{ACKNOWLEDGEMENTS}

We would like to thank Prof. João Alfredo Medeiros and the technicians Adailton Orçai Fialho and Matias Ramos de Azevedo (Laboratório de Análise Ambiental e Mineral - I.Q./UFRJ, Brazil) for measuring cadmium concentration as well as Prof. Ricardo Chaloub and Vânia Gomes Leal (Depto. de Bioquímica - I.Q./ UFRJ, Brazil) for the use of the spectrofluorimeter. This work was supported by grants from FAPERJ and CNPq. 


\section{RESUMO}

\section{Fatores envolvidos na absorção de cádmio por uma cepa selvagem de Saccharomyces cerevisiae}

Na concentração usada neste trabalho (10 ppm), cádmio foi removido eficientemente do meio ambiente por células de leveduras de fase estacionária do crescimento. Enquanto células coletadas na fase exponencial demonstraram uma baixa capacidade de absorção, células de fase estacionária do crescimento removeram $97 \%$ do cádmio do meio em $24 \mathrm{~h}$. Verificamos ainda que células mortas não foram capazes de absorver cádmio. Independentemente da fase do crescimento em que eram coletadas, as células apresentaram uma alta tolerância à $10 \mathrm{ppm}$ de cádmio: cerca de $80 \%$ das células mantinham-se viáveis após $24 \mathrm{~h}$ de exposição ao metal. No entanto, quando as células foram inicialmente desidratadas, a tolerância ao metal caiu drasticamente. Utilizando uma prova fluorescente sensível ao nível de espécies reativas de oxigênio, observamos que quando as células de levedura absorvem cádmio do meio há um aumento do nível de oxidação intracelular, o qual pode ser responsável pelos efeitos tóxicos do metal. Extratos de células de fase estacionária, quando tratadas com metal, apresentaram um aumento de cerca de 10 vezes no nível de fluorescência, o que não foi observado em células de fase exponencial. Células desidratadas quando expostas ao cádmio, apresentaram um aumento no nível de oxidação intracelular, mas este efeito foi provocado principalmente pelo processo de desidratação.

Palavras-chaves: Saccharomyces cerevisiae, cádmio, absorção, oxidação.

\section{REFERENCES}

1. Ayres, R.U. Toxic heavy metals: materials cycle optimization. Proc. Natl. Acad. Sci. USA., 89: 815-820, 1992.

2. Beker, M.J.; Rapaport, A.I. Conservation of yeasts by dehydration. In: Advances in Biochemical Engineering. Berlin: Springer-Verlag, 1987, p. 128-170.

3. Brennan, R.J.; Schiestl, R.H. Cadmium is an inducer of oxidative stress in yeast. Mutat. Res., 356: 171-178, 1996.

4. Chrestensen, C.A.; Starke, D.W.; Mieyal, J.J. Acute cadmium exposure inactivates thioltransferase (glutaredoxin), inhibits intracellular reduction of protein-glutathionyl mixed disulfides, and initiates apoptosis. J. Biol. Chem., 275: 26556-26565, 2000.

5. Clemens, S.; Antosiewicz, D.M.; Ward, J.M.; Schachtman, D.P.; Schroeder, J.I. The plant cDNA $L C T 1$ mediates the uptake of calcium and cadmium in yeast. Proc. Natl. Acad. Sci. U.S.A., 95: 1204312048, 1998.

6. Davidson, J.F.; Whyte, B.; Bissinger, P.H.; Schiestl, R.H. Oxidative stress is involved in heat-induced death in Saccharomyces cerevisiae. Proc. Natl. Acad. Sci. U.S.A., 93: 5116-5121, 1996.
7. Eleutherio, E.C.A.; Araújo, P.S.; Panek, A.D. Role of trehalose carrier in dehydration resistance of Saccharomyces cerevisiae. Biochim. Biophys. Acta, 1156: 263-266, 1993.

8. Eleutherio, E.C.A.; Ribeiro, M.J.S.; Pereira, M.D.; Maia, F.M.; Panek, A.D. Effect of trehalose during stress in a heat-shock resistant mutant of Saccharomyces cerevisiae. Biochem. Mol. Biol. Int., 36: 12171223, 1995.

9. Gadd, G.M.; White, C. Microbial treatment of metal pollution - a working biotechnology? Tibtech., 11: 353-359, 1993.

10. Gelmi, M.; Apostoli, P.; Cabibbo, E.; Porru, S.; Alessio, L.; Turano, A. Resistance to cadmium salts and metal absorption by different microbial species. Curr. Microbiol., 29: 335-341, 1994.

11. Gomes, D.S.; Fragoso, L.C.; Riger, C.J.; Panek, A.D.; Eleutherio, E.C.A. Regulation of cadmium uptake by Saccharomyces cerevisiae. Biochim. Biophys. Acta, 1573: 21-25, 2002.

12. Guerinot, M.L. The ZIP family of metal transporters. Biochim. Biophys. Acta, 1465: 190-198, 2000.

13. Hallenbeck, W.H. Human health effects of exposure to cadmium. Experientia Suppl., 50: 131-137, 1986.

14. Howlett, N.G.; Avery, S.V. Induction of lipid peroxidation during heavy metal stress in Saccharomyces cerevisiae and influence of plasma membrane fatty acid unsaturation. Appl. Env. Microbiol., 2971-2976, 1997.

15. Kang, K.J. Exogenous glutathione decreases cellular cadmium uptake and toxicity. Drug Met. Dis., 20: 714-718, 1992.

16. Liao, V.H.; Freedman, J.H. Cadmium-regulated genes from the nematode Caenorhabditis elegans. J. Biol. Chem., 273: 3196231970, 1998.

17. Loviey, D.R.; Coates, J.D. Bioremediation of metal contamination. Curr. Opin. Biotechnol., 8: 285-289, 1997.

18. Maquieira, A.; Elmahadi, H.A.M.; Puchades, R. Use of Saccharomyces cerevisiae in flow injection atomic absorption spectrometry for trace metal concentration. Anal. Chem., 66: 1462$1467,1994$.

19. Muller, E.M.; Locke, E.G.; Cunningham, K.W. Differential regulation of two $\mathrm{Ca}(2+)$ influx systems by pheronmone signaling in $S$. cerevisiae. Genetics, 159: 1527-1538, 2001.

20. Rota, C.; Fann, Y.C.; Mason, R.P. Phenoxyl free radical formation during the oxidation of the fluorescent dye 2',7'-Dichlorofluorescein by horseradish peroxidase. J. Biol. Chem., 274: 28161-28168, 1999.

21. Sola, S.; Barrio, T.; Martín, A. Cadmium and lead in pork and duck pastes produced in Spain. Food Addit. Contam., 15: 580-584, 1998.

22. Stohs, S.J.; Bagchi, D. Oxidative mechanisms in the toxicity of metal ions. Free Rad. Biol. Med., 18: 321-336, 1995.

23. Tohoyama, H.; Inouhe, M.; Joho, M.; Murayama, T. Production of metallothionein in cooper- and cadmium- resistant strains of Saccharomyces cerevisiae. J. Ind. Microbiol., 14: 126-131, 1995.

24. Tsuchiya, M.; Suematsu, M. In vivo visualization of oxygen radicaldependent photoemission. In: Methods in Enzymology. USA: Academic Press Inc., 1994, p. 128-140.

25. Valentine, J.S.; Wertz, D.L.; Lyons, T.J.; Liou, L.; Goto, J.; Gralla, E.B. The dark side of dioxygen biochemistry. Curr. Opin. Chem. Biol., 2: 253-262, 1998.

26. Volesky, B. Advances in biosorption of metals: selection of biomass types. FEMS Microbiol. Rev., 14: 291-302, 1994.

27. Werner-Washburne, M.; Braun, E.; Johnston, G.C.; Singer, R.A. Stationary phase in the yeast. Microbiol. Rev., 57: 383-401, 1993.

28. Yurkow, E.J.; McKenzie, M.A. Characterization of hypoxiadependent peroxide production in cultures of Saccharomyces cerevisiae using flow cytometry: a model for ischemic tissue destruction. Cytometry, 14: 287-293, 1993. 